\title{
APPLICABLE LAW IN THE ABSENCE OF CHOICE TO CONTRACTS RELATING TO INTELLECTUAL OR INDUSTRIAL PROPERTY RIGHTS
}

\author{
Pedro Alberto DE MIGUEL ASENSIO *
}

Published in / Publicado en:

Yearbook of Private International Law, vol. X, 2008, pp. 199-219

* Catedrático de Derecho internacional privado Facultad de Derecho Universidad Complutense de Madrid E- 28040 MADRID pdmigue@der.ucm.es

Documento depositado en el archivo institucional EPrints Complutense http://eprints.ucm.es 


\begin{abstract}
Choice of law issues concerning contracts having intellectual or industrial property rights as their subject matter have traditionally been very controversial in all jurisdictions. This article deals with the applicable law under the new European conflict rules for contracts when a choice of law has not been made by the parties. Hence, its subject matter is the interpretation of Article 4 of the 2008 Rome I Regulation in the area of contracts relating to intellectual or industrial property rights. The lack of a specific provision on these contracts in the new Regulation may be a source of uncertainty and demands a special effort to provide guidelines to ensure its uniform interpretation in this field.
\end{abstract}

Keywords: Licence and Assignment, International Contracts, Intellectual Property, Applicable Law, Characteristic Performance, Rome II Regulation

\title{
RESUMEN
}

La determinación de la ley aplicable a los contratos internacionales sobre derechos de propiedad industrial e intelectual resulta especialmente compleja en la mayor parte de los sistemas de DIPr. Este artículo analiza el tratamiento de esos contratos en el nuevo régimen europeo de determinación de la ley aplicable a los contratos internacionales. Se centra, por lo tanto en la interpretación del artículo 4 del Reglamento Roma II a esta categoría de contratos. La ausencia de una regla específica sobre los contratos relativos a derechos de propiedad industrial e intelectual puede ser una fuente de inseguridad jurídica, lo que reclama un especial esfuerzo por desarrollar criterios que aseguren su interpretación uniforme en este ámbito.

Palabras claves: Licencia y cesión, contratos internacionales, propiedad industrial e intelectual, derecho aplicable, prestación característica, Reglamento Roma II 


\title{
APPLICABLE LAW IN THE ABSENCE OF CHOICE TO CONTRACTS RELATING TO INTELLECTUAL OR INDUSTRIAL PROPERTY RIGHTS
}

\author{
Pedro A. De Miguel Asensio*
}

\author{
I. Introduction \\ II. The New Structure of Article 4 \\ III. Significance of the Categories of Contracts Covered by Article 4(1) \\ IV. Characteristic Performance \\ V. Recourse to the Escape Clause \\ VI. Determination of the Country with the Closest Connection to the Contract
}

\section{Introduction}

The typology of international contracts having intellectual or industrial property (IP) rights as their subject matter encompasses multiple categories of agreements that combine a great variety of clauses. This is only one factor influencing the choice of law issues concerning these contracts which have traditionally been very controversial in all jurisdictions. From a comparative perspective, national systems have envisaged very different solutions. Even among countries whose Private International Law ('PIL') systems are based on similar principles, significant divergences can be found to the extent that they have enacted specific conflict-of-law rules for these contracts. ${ }^{1}$ In most systems the lack of specific provisions has been an additional source of uncertainty. This has also been the situation concerning the interpretation of the 1980 Rome Convention on the law applicable to contractual obligations. The difficulties in identifying the characteristic performance and the opposing views with respect to the relationship between paragraphs 2 and 5 of Article 4 have led to a disparity of views on the law applicable to these contracts and have seriously undermined predictability. The 2005 Proposal for a Regulation on the law applicable to contractual obligations (Rome I) ${ }^{2}$ included in paragraph 1 of Article 4 a particular rule on the law applicable to 'a contract relating to intellectual or industrial property rights'

\footnotetext{
* Professor at the Law Faculty of the Universidad Complutense, Madrid.

${ }^{1}$ For instance, under Article 122 of the 1987 Swiss Private International Law Act, the law applicable to contracts relating to industrial or intellectual property rights shall be the law of the habitual residence of the transferor or licensor. By contrast, under the 1978 Austrian Private International Act, those contracts were governed by the law of the protecting country or, in the case of contracts for more than one country, the law of the habitual residence of the transferee or licensee. See paragraph 43(1) that was replaced by the Rome Convention, FALLENBÖCK M., 'Zur kollisionsrechtlichen Anknüpfung von Immaterialgüterrechtsverträgen nach dem Europäischen Vertragsrechts- übereinkommen (EVÜ)', in: ZfRV 1999, at 98-102.

${ }^{2}$ COM (2005) 650 final, 15.12.2005.
} 
aimed at enhancing certainty by means of a precise rule on the law applicable in the absence of a choice. ${ }^{3}$ However, such a rule was suppressed during the decision-making process, and hence, it has not been included in the final text of Article 4 Regulation (EC) No 593/2008 (Rome I Regulation) which contains no particular reference to those contracts.

Choice of law agreements are very common in international practice since they are the best instrument to enhance certainty between the parties. A significant number of international contracts in this area, however, do not include an effective agreement on the issue. ${ }^{4}$ This article deals only with the applicable law under the new European conflict rules for contracts when a choice of law has not been made by the parties. Hence, its subject matter is the interpretation of Article 4 of the 2008 Rome I Regulation in the field of contracts relating to intellectual or industrial property rights. Therefore, other issues that may be very significant in regulating these international contracts are left aside. Those issues include, in particular, the determination of the limits between the scope of the law of the contract and the scope of the law(s) of protection of the exclusive rights covered by the contract, $^{5}$ the applicability of the specific provisions on consumer contracts (Article 6 Rome I Regulation), ${ }^{6}$ and the application or effects of overriding mandatory provisions (Article 9 Rome I Regulation).

\section{The New Structure of Article 4}

The provisions on the law applicable in the absence of an express or implied choice by the parties are among those in which the transformation of the Rome Convention into a Regulation has resulted in the introduction of relevant amendments to the previous text. ${ }^{7}$ The interpretation of the new text and the

\footnotetext{
${ }^{3}$ For a critical appraisal of that rule, see EUROPEAN MAX-PLANCK GROUP FOR CONFLICT OF LAWS In INTELleCtUAL PROPERTY (CLIP), 'Comments on the European Commission's Proposal for a Regulation on the Law Applicable to Contractual Obligations (Rome I) of December 15, 2005 and the European Parliament Committee on Legal Affairs' Draft Report on the Proposal of August 22, 2006', in: IIC 2006, at 471.

${ }^{4}$ About the reasons for this situation, see DESSEMONTET F., 'L'harmonisation du droit applicable aux contrats de licence', in: Mélanges A.E. von Overbeck, Fribourg 1990, at 725-739; ZENHÄUSERN U., Der internationale Lizenzvertrag, Fribourg 1991, at 90; HIESTAND M., Die Anknüpfung internationaler Lizenzverträge, Frankfurt 1993, at 151; and TORREMANS P., 'Choiceof-Law Problems in International Industrial Property Licences', in: IIC, 1994, at 390-391.

${ }^{5}$ De Miguel Asensio P.A., Contratos internacionales sobre propiedad industrial, $2^{\text {nd }}$ ed., Madrid 2000, at 163-185.

${ }^{6}$ DREXL J., 'Which Law Protects Consumers and Competition in Conflict with Intellectual Property Rights?', in: BASEDOw J. / DREXL J. / KUR A. / METZGer A., Intellectual Property in the Conflict of Laws, Tübingen 2005, at 79-106.

${ }^{7}$ GARCIMARTín AlFÉREZ F.J., 'El Reglamento «Roma I» sobre ley aplicable a las obligaciones contractuales: ¿Cuánto ha cambiado el Convenio de Roma de 1980?’, in: La Ley, num. 6957, 2008, at IV; LEIBLE S. / LEHMANN M., 'Die Verordnung über das auf vertragliche Schuldverhältnisse anzuwendende Recht («Rom I»)', in: RIW 2008, p. 528 et seq., at 534-536; and UBERTAZZI B., Il regolamento Roma I sulla legge applicabile alle obbligazioni contrattuali, Milan 2008 , at 67 et seq.
} 
assessment to what extent it departs from the previous Article 4 deserve special attention given the pivotal role of those provisions in the conflict-of-laws system on international contracts.

A basic underlying principle of Article 4 both in the Rome Convention and the Regulation is the so-called proximity principle that is founded on the idea that the applicable law should be that of the country with which the contract is most closely connected. However, this basic principle may lead to uncertainty in the law-finding process since, in the absence of specific criteria regarding its application, courts have a significant degree of discretion to determine the applicable law. By contrast, clear and reliable indications for the parties and the judge concerning the law applicable in the absence of choice contribute to reduce litigation. The new Regulation stresses that it is possible to achieve its general objective of contributing to legal certainty in the European judicial area only with highly predictable conflict-of-law rules. ${ }^{8}$ The changes introduced in Article 4 are to a great extent aimed at achieving a clearer and more precise balance between conflicts justice - or proximity - and legal certainty with a view to ensure a sufficient level of predictability.

It is noteworthy that the content of the first paragraph of Article 4 Rome Convention has as such disappeared in the Regulation. That paragraph proclaimed the basic principle that the contract shall be governed by the law of the country with which it is most closely connected. That idea is also essential in the new Article 4, as illustrated by the escape clause contained in paragraph 3 and the default rule of paragraph 4 . However, Article 4 now begins with a new provision establishing the law applicable to certain categories of contracts by means of fixed and direct rules that only in exceptional circumstances may be disregarded. Additionally, the suppression of the express reference contained in Article 4(1) Rome Convention to the possibility that a severable part of the contract which has a closer connection with another country may be governed by the law of that other country seems related to the exceptional character of such mechanism and the additional risks it poses to legal certainty.

A crucial element to the functioning of Article 4 Rome Convention was the existence of three presumptions concerning the law most closely connected with certain categories of contracts. Under the general presumption of paragraph 2 , it is presumed that the contract is most closely connected with the country where the party who is to effect the performance which is characteristic of the contract has, at the time of conclusion of the contract, his habitual residence or its central administration. Specific provisions were provided for in paragraphs 3 and 4 for two categories of contracts to which the characteristic performance rule did not apply. Concerning contracts whose subject matter is a right in, or a right to use, immovable property it is presumed under Article 4(3) that the contract is most closely connected with the country where the immovable property is situated. Paragraph 4 was devoted to contracts for the carriage of goods.

In practice, that system and its application by national courts raised significant difficulties that seriously undermined the predictability of the law applicable

\footnotetext{
${ }^{8}$ See paragraph 16 of the Preamble.
} 
under Article 4 Rome Convention and the uniform interpretation of its provisions by the courts of the Member States. The determination of which performance is characteristic (or even if it is possible to establish a performance as characteristic) was frequently a source of controversy between parties (and academics) and led to different solutions in different Member States. Such disparities arose even with regard to certain types of contracts frequently used in international business, such as exclusive distribution agreements ${ }^{9}$ and franchise contracts. Since the determination of the characteristic performance becomes more difficult the more complex the relevant contract is, the issue was controversial concerning many contracts relating to intellectual or industrial property rights.

In order to avoid or at least limit these difficulties and to reinforce legal certainty, the new Article 4 rests on a different approach concerning the role of the characteristic performance. The new Article 4 now only requires identification of the characteristic performance to determine the governing law in those cases where the contract cannot be categorised as being one of the specified types listed in the new paragraph 1 or where the elements of the contract fall within more than one of those types as provided for in the new paragraph 2 . Hence, inasmuch as the contract may be characterised as falling within one of the categories of paragraph 1 , the existence of conflicting views about which is the characteristic performance in those contracts loses its previous significance. In practice, the categories of contracts listed in the new paragraph 1 encompass a very significant percentage of international agreements since the list includes: sale of goods; contracts for the provision of services; contracts relating to a right in rem in immovable property or to a tenancy of immovable property; franchise contracts; distribution contracts; sale of goods by auction; and contracts concluded within regulated markets in financial instruments. Contrary to paragraphs 2 to 4 of Article 4 of the Rome Convention, Article 4(1) of the Regulation is not drafted as a series of presumptions but as rules that determine the law of the country applicable to each of those categories of contracts. The introduction of fixed rules establishing which is the governing law represents a significant evolution of Article 4 Rome Convention and, in practice, increases legal certainty especially regarding those categories of contracts in which the determination of the characteristic performance is controversial and that are now listed in Article 4(1) such as distribution and franchise contracts.

The wording and complex structure of Article 4 of the Rome Convention have made possible different interpretations regarding the interaction between the presumption based on the characteristic performance and the escape clause contained in paragraph 5. ${ }^{10}$ According to this provision, the presumptions established in paragraphs 2, 3 and 4 shall be disregarded if it appears from the circumstances as a whole that the contract is more closely connected with another country. Diverging views in regards to the interplay between the presumptions and the escape clause result in different approaches when examining the balance between

\footnotetext{
${ }^{9}$ MANKowsKi P., 'Der Vorschlag für die Rom I-Verordnung', in: IPRax 2006, pp. 101-113, at 103-104.

${ }^{10}$ See, e.g., Martiny D., in: Reithmann C. / MARTiny D., Internationales Vertragsrecht, $6^{\text {th }}$ ed., Köln 2004, at 129-130.
} 
'conflicts justice' (proximity) and legal certainty and result in different solutions when determining the governing law to similar situations under Article 4 of the Rome Convention. The case-law concerning the application of Article 4 of the Convention provides significant examples of the influence of such divergent views in the different Member States or even between the courts of the same State. ${ }^{11}$

If a broad and flexible view is taken regarding the ability to disregard the presumptions, this may in practice seriously undermine legal certainty in the determination of the law applicable to international contracts because it may lead to a case-by-case assessment of the particular contacts that a contract has with the different countries even in the situations covered by the presumptions. That approach broadens the degree of judicial discretion by weakening the significance of the presumptions. Hence, it is no surprise that certain courts have tended to favour that interpretation. ${ }^{12}$ By contrast, other courts have favoured an interpretation of the escape clause that stresses its nature as an exception in those cases in which one of the presumptions applies. ${ }^{13}$ Such a view favours legal certainty and seems to be coherent with the system established in Article 4 Rome Convention and the rationale of the presumptions ${ }^{14}$ that were introduced in the Convention to substantially limit the flexibility of the general principle established by paragraph

\footnotetext{
${ }^{11}$ In the UK, most English decisions have opted for a weak presumption theory, disregarding the characteristic performance presumption of paragraph 2 when the characteristic performer's principal place of business is not the country of the place of performance of the characteristic obligation, see Samcrete Egypt Engineers and Contractors SAE v Land Rover Exports Ltd ([2002] CLC 533), Kernburn Waste Management Ltd v Bergmann ([2002] CLC 644) and Definitely Maybe Touring Ltd. v. Marek Lieberberg Konzertagentur GmbH ([2001] 2 Lloyd's Rep. 455); by contrast, in Scotland the Court of Session has clearly adopted the strong presumption approach, see Caledonian Subsea Ltd. v. Micoperi Srl ([2001] SC 716 (OH); 2003 SC 70).

${ }^{12}$ As illustrated by English practice, see HILL J., 'Choice of Law in Contract under the Rome Convention: the Approach of the UK Courts', in: ICLQ 2004, p. 325 et seq., at 339-343. See also, in Italy the judgment of the Corte di Cassazione of 10.03.2000 in Krauss Maffei Verfahrenstechnik GmbH, Kraus Maffei AG v. Bristol Myers Squibb S.p.A., considering that a contract for the sale of technical equipment, which includes for the seller also an obligation to install and guarantee the functioning of the goods, is governed by the law of the country where those obligations are to be performed (place of the buyer).

${ }^{13}$ Most prominent is the judgment of 25.09 .92 by the Dutch Hoge Raad in Sociéte Nouvelle des Papéteries v. Machinenfabrik; discussing that judgment and its implications, see RAMMELOO S., 'Die Auslegung von Art. 4 Abs. 2 und Abs. 5 EVÜ: Eine niederländische Perspektive', in: IPRax 1994, at 243; and Struycken T., 'Some Dutch Reflections on the Rome Convention, Art 4(5)', in: LMCLQ 1996, at 18. See also, e.g., in Germany, Bundesgerichtshof, judgment of 25.02.1999 (NJW 1999, at 2442-2443), holding that the presumption of the characteristic performance applies for international construction contracts and that a construction site cannot be regarded as a closer connection under Article 4(5); and in Spain, Audiencia Provincial de Barcelona, judgment of 21.03.2003 (JUR 2003, 199804), considering that the law applicable to a contract of sale under Article 4 is the law of the seat of the party who is to effect the characteristic performance (seller) irrespective of the place of delivery and installation of the machines that were the subject matter of the contact.

${ }^{14}$ See KREUZER K., 'Zur Funktion von kollisionsrechtlichen Berichtigungsnormen', in: ZfRV 1992, p. 168, at 175-176; and MARMISSE A., 'Autonomie de la volonté et principe de proximité dans Bruxelles I et dans Rome I', in: Enforcement of International Contracts in the European Union, Antwerpen 2004, pp. 255-268, at 266.
} 
1. Further, it gives specific form and objectivity to the concept of 'closest connection' which by some was considered as too vague. In this connection, it was acknowledged in the Report to the Convention that the presumption based on the characteristic performance was aimed at greatly simplifying the determination of the applicable law, and that in typical situations in which a characteristic performance may be established, seeking the place where the contract was concluded or the different places of performance and classifying them becomes superfluous. ${ }^{15}$ In order to enhance legal certainty, the wording of the new Article 4 reinforces the view that only a restrictive interpretation of the escape clause is compatible with the general objective of the Regulation. Indeed, the escape clause of Article 4(3) Rome I Regulation makes it clear that it is only to be applied in cases in which the contract is 'manifestly more closely connected with a country other than that indicated in paragraphs 1 or 2.' Additionally, paragraphs 1 and 2 are not drafted as presumptions, although their rules may be disregarded when the conditions to apply the escape clause are met. Hence, it can be concluded that, as regards the role of the escape clause, the new Article 4 mainly reviews the wording of the Rome Convention in order to make clearer its nature as an exceptional device. The final result is in line with the approach that favoured a strong presumption approach and a restrictive interpretation of the escape clause of Article 4(5) of the Convention. Therefore, the Regulation grants a certain degree of discretion to the courts, which is in contrast to the initial 2005 Proposal made by the Commission that not only envisaged the conversion of the mere presumptions into fixed rules, establishing hard-and-fast connecting factors, but also was intended to abolish the escape clause. ${ }^{16}$

\section{Significance of the Categories of Contracts Covered by Article 4(1)}

Under Article 4 Rome I Regulation the first step to determine the applicable law is to assess if the contract can be categorised as being one of the specified types listed in paragraph 1. If that is the case, the applicable law is determined in accordance with the fixed rules of paragraph 1, and the resulting law can only be disregarded under the exception clause of Article 4(3) of the Regulation.

The rules specified in Article 4(1) Rome I Regulation for the types of contracts listed in that provision establish fixed connecting factors that are considered the relevant elements to locate each group of contracts in the country where its centre

\footnotetext{
${ }^{15}$ As stated in the comments on Article 4 contained in GIULIANO M. / LAGARDE P., 'Report on the Convention on the law applicable to contractual obligations' (OJ C 282, 31.10.1980, at 1).

${ }^{16}$ LAGARDE $\mathrm{P}$., 'Remarques sur la proposition de règlement de la Commission européenne sur la loi applicable aux obligations contractuels (Rome I)', in: Rev. crit. dr. int. pr. 2006, at 331-338; Max Planck Institute For Foreign Private And Private International Law, 'Comments on the European Commission's Proposal for a Regulation of the European Parliament and the Council on the law applicable to contractual obligations (Rome I)', in: RabelsZ 2007, at 225-344; and FERRARI F., 'Objektive Anknüpfung', in: FERRARI F. / LEIBLE S., Ein neues Internationales Vertragsrecht für Europa, Jena 2007, pp. 57-87, at 72.
} 
of gravity is situated. Sometimes the criterion chosen is the habitual residence of one of the parties. Indeed, some rules make explicit the widely accepted result of applying to the relevant groups of contracts the characteristic performance concept. That is the case, in particular, with paragraph (a), which establishes that a contract for the sale of goods shall be governed by the law of the country where the seller has his habitual residence, and paragraph (b), which states that a contract for the provision of services shall be governed by the law of the country where the service provider has his habitual residence. Also, paragraphs (e) and (f) refer to the habitual residence of one of the parties as the connecting factor: a franchise contract shall be governed by the law of the country where the franchisee has his habitual residence (paragraph e); and a distribution contract shall be governed by the law of the country where the distributor has his habitual residence (paragraph f). However, these two provisions seem to have their own rationale. It results from the original Proposal by the Commission that those rules are not the product of a new consensus as to which is the characteristic performance of those types of contracts but rather reflects a choice by the drafters of the Regulation as to the appropriate connecting factor after considering especially the fact that Community law seeks to protect the franchisee and the distributor as the weaker parties. ${ }^{17}$

The centre of gravity idea is clearly the rationale behind the connecting factors used in paragraphs (c), (d), (g) and (h) of Article 4(1) Rome I Regulation. Paragraphs (c) and (d) refer to contracts relating to a right in rem in immovable property or to a tenancy of immovable property, and state that they shall be governed by the law of the country where the property is situated; however, certain contracts relating to a tenancy of immovable property concluded for temporary private use shall be governed by the law of the country where the landlord has his habitual residence provided that the tenant has his habitual residence in the same country. ${ }^{18}$

One of the categories of contracts listed in Article 4(1) of the 2005 Proposal presented by the Commission referred to contracts relating to intellectual or industrial property rights. According to Article 4(1)(f) of the Proposal, those contracts should be governed by the law of the country in which the person who transfers or assigns the rights has his habitual residence. Such a provision was intended to establish a fixed criterion common to all contracts having as their main object the transfer or licence of intellectual or industrial property rights. The suppression during the legislative process of this provision was mainly due to the impossibility of finding a fixed rule capable of providing an adequate response to the diverse typology of IP contracts that have developed in business practice. ${ }^{19}$ Indeed, the

\footnotetext{
${ }^{17}$ As it was expressly stated in the Explanatory Memorandum of the 2005 Commission's Proposal, COM (2005) 650 final, at p. 6. This represents the inclusion of new policy goals in Article 4, see, LEIBLE S. / LEHMANN M. (note 7), at 535.

${ }^{18}$ Under paragraph $(\mathrm{g})$ the relevant connecting factor as regards contracts for the sale of goods by auction is the country where the auction takes place, if such a place can be determined. Finally, according to paragraph (h), the applicable law to contracts concluded within regulated markets in financial instruments shall be the law of the country that governs the relevant market.

${ }^{19}$ GARCIMARTín ALFÉREZ F.J. (note 7), at IV.1.
} 
differences as regards the subject matter, the content, the scope of parties' obligations or the territorial reach of licenses and assignments, and the complex nature of many of the agreements that include in their object industrial or intellectual property rights, make it almost impossible to establish an appropriate solution for all of those contracts in a single rule. Additionally, the wording of the proposal was too broad because in many contracts the assignment or licence of industrial or intellectual property rights is only ancillary, especially in distribution, franchise, and joint-venture agreements. The lack of specific reference in the Regulation to these contracts may prove to be a source of uncertainty. ${ }^{20}$

Given the structure of Article 4 Rome I Regulation, the following steps should be followed in order to determine the law applicable in the absence of choice to contracts relating to intellectual or industrial property rights. First, it has to be ascertained whether the relevant contract can be categorised as falling within only one of the types of contracts set forth in Article 4(1). If the response is negative, it will be necessary to find out if it is possible to determine the habitual residence of the characteristic performer. Hence, the determination of the characteristic performance still plays a significant role in these contracts. Only if the law applicable cannot be determined on the basis of the characteristic performance criterion, then it shall be necessary to establish which country is most closely connected with the contract. Finally, the law applicable by virtue of these rules may be disregarded in exceptional cases by virtue of the escape clause of Article $4(3)$ of the Rome I Regulation.

As regards the first step, several categories of contracts listed in Article 4(1) may be relevant when determining the law applicable to contracts having as their subject matter intellectual or industrial property rights. In particular, franchise agreements are complex contracts that typically include in their object the licensing of certain exclusive rights (such as trademarks or copyrights) and also know-how. The inclusion of a special rule on franchise contracts in Article 4(1)(e) and the lack of a rule on IP contracts determines the applicability of the special provision to all franchise contracts, including master franchise agreements, irrespective of the presence of intellectual or industrial property rights in the object of the contract. Under the fixed rule of paragraph (e), the law applicable shall be that of the country where the franchisee has his habitual residence. As already noted, this fixed rule, which aimed also at enhancing the protection of franchisees who have been typically viewed as weaker parties, shall contribute to increase the predictability of the law applicable to franchise contracts, since under the system of the Rome Convention, the determination of the party required to effect the characteristic performance and the identification of a characteristic performance in these contracts were especially uncertain and controversial. ${ }^{21}$

Some other types of contracts listed in Article 4(1) may in practice include provisions relating to intellectual or industrial property rights. In particular, distribution contracts may include a grant to the distributor to use certain trademarks.

${ }^{20}$ AzZI T., 'Les contrats d'exploitation des droits de propriété littéraire et artistique en Droit international privé: état des questions', in: RIDA 2007, p. 3 et seq., at 41.

${ }^{21}$ See HIESTAND M., 'Die international-privatrechtliche Beurteilung von Franchiseverträgen ohne Rechtswahlklausel', in: RIW 1993, at 173-179. 
As already stated with respect to franchising, inasmuch as an agreement falls within the category of a distribution contract in the terms of Article 4(1)(f ) Rome I Regulation, the criteria that the contract shall be governed by the law of the country where the distributor has his habitual residence applies irrespective of the presence of IP rights in its subject matter.

The possible classification of contracts relating to intellectual or industrial property rights as contracts for the provision of services in order to be covered by Article 4(1)(b) Rome I Regulation may raise additional uncertainty. Under that rule, a contract for the provision of services shall be governed by the law of the country where the service provider has his habitual residence. The Rome I Regulation seems to be based on a broad understanding of service contracts since its Preamble states that franchise and distribution contracts are contracts for services even though they are the subject of specific rules. ${ }^{22}$ Since there are no special rules for contracts relating to intellectual or industrial property rights under Article 4.1 of the Regulation, paragraph (b) should be decisive to the extent that contracts relating to those rights are to be regarded as contracts for services in the context of that provision. With respect to the interpretation of the concept of provision of services in Article 4.1 Rome I Regulation, its Preamble also stresses that it should be interpreted in the same way as when applying Article 5 of Regulation 44/2001 insofar as provision of services is covered by that Regulation. Given these facts, a reference for a preliminary ruling from the Oberster Gerichtshof (Austria) lodged on 29 November 2007 and currently pending before the European Court of Justice (ECJ) may be of special interest in this connection. ${ }^{23}$ The first question referred to the ECJ seeks to clarify whether a licence agreement - a contract under which the owner of an incorporeal right grants the other contracting party the right to use that right - is a contract regarding 'the provision of services' within the meaning of Article 5(1)(b) of the Brussels I Regulation or not.

The view that licensing contracts in general are contracts for the provision of services could result in a concept of contract for services much broader than the one originally envisaged by the drafters of the Brussels I and Rome I Regulations, especially in those situations in which the licensor only grants the right to use the object of the licence and does not perform any additional activity, as stressed by AG Trstenjak in her Opinion in case C-533/07. However, it is important to note that the typology of contracts relating to intellectual or industrial property rights is very diverse and encompasses agreements that may be classified as contracts for the provision of services in the context both of Article 5(1)(b) Brussels I Regulation and Article 4(1)(b) Rome I Regulation. That should be the case for agreements where the permission for use granted to the licensee by the owner of the IP right is functionally subordinate to the main obligation of one of the parties to provide certain services to the other party. For instance, it may happen that a contract combines a patent licence with the obligation of the licensor to provide technical assistance and train the licensee's personnel in a much broader

\footnotetext{
${ }^{22}$ See paragraph 17 of the Preamble.

${ }^{23}$ Case C-533/07, Falco Privatstiftung and Thomas Rabitsch v Gisela Weller-Lindhorst (OJ C 37/15 of 9.2.2008). Advocate General Trstenjak delivered her Opinion on 27 January 2009.
} 
technological area so that in fact the obligations relating to the patent licence are economically and functionally less significant than the promise to provide services to the other party. Such characterization may also be appropriate for some categories of research and development agreements in which the researcher or developer is granted the right to use technology owned by the other party. Regardless of the presence of licensing or assigning obligations, to the extent that the research or development obligations of one of the parties are envisaged as the main object of the contract, it may be possible to characterize it as a contract for the provision of services falling within the scope of Article 4(1)(b) Rome I Regulation. Notwithstanding the relevant differences as to the structure and contents of the agreements, the same result may be appropriate with respect to certain software development agreements. To the extent that the relevant contract may be classified as a contract for the provision of services under Article 4(1), the law applicable should be the law of the country where the service provider has his habitual residence.

It may also occur that contracts relating to intellectual or industrial property rights in certain categories of licences fall at the same time within both the category of contracts for the provision of services and other types of contracts specified in Article 4(1) of the Rome I Regulation. That may be the case of a so-called production and supply contract with respect to patented products. This kind of contract is characterized as a production license without a marketing and sales license within the framework of a supply contract. The licensee is obliged to produce certain products using the technology of the licensor and to supply the products to the licensor who in turn promises to buy all of the products made by the licensee who is not visible in the market as an independent supplier. ${ }^{24}$ Given these features, although the agreement comprises a licence in the framework of Article 4(1) Rome I Regulation, it seems to fall in part within the contract for the sale of goods classification - as regards the obligation to supply the goods - and in part a contract for the provision of services - concerning the production of the goods by the licensee. ${ }^{25}$

According to Article 4(2) Rome I Regulation, where the contract is not covered by paragraph 1 or where the elements of the contract would be covered by more than one of points (a) to (h) of paragraph 1 , the contract shall be governed by the law of the country where the party required to effect the characteristic performance of the contract has his habitual residence. The Preamble of the Regulation states in paragraph 19 that in the case of a contract consisting of a bundle of rights and obligations falling within more than one of the types of contracts listed in paragraph 1, the characteristic performance of the contract should be determined according to its centre of gravity. In a contract such as the production and supply

\footnotetext{
${ }^{24}$ PAgenberg J. / Geissler B., Lizenzverträge, (License Agreements), $3^{\text {rd }}$ ed., Köln 1991, at 306329.

${ }^{25}$ In the context of Article 5(1) Brussels I Regulation, the qualification of contracts concerning the delivery of goods to be produced and delivered to the other party in accordance with its specifications as sale of goods or provision of services remains controversial, pending a preliminary ruling on that issue referred to the ECJ by the Bundesgerichtshof (Germany) on 09.07.08.
} 
agreement mentioned above, the fact that both paragraph (a) - sale of goods - and paragraph (b) - provision of services - lead to the application of the law of the country of the habitual residence of the same party - the producer or supplier who is also the licensee - makes it possible to identify that party as the one who is to effect the characteristic performance in such a contract for the purposes of Article 4(2) Rome I Regulation.

\section{Characteristic Performance}

Article 4(2) Rome I Regulation does not provide any indications on how to establish what party is to effect the characteristic performance of a given contract. The comments on Article 4 in the Report on the 1980 Rome Convention stressed that recourse to the characteristic performance defines the connecting factor of the contract from the inside based on elements related to the essence of the obligation and on the function that the legal relationship involved fulfils in the economic and social life of any country. Concerning the determination of the characteristic performance, the Report stated that in bilateral contracts whereby the parties undertake mutual reciprocal performances, the counter-performance by one of the parties usually takes the form of money and this is not the characteristic performance. It is the performance for which the payment is due - such as the delivery of goods, the granting of the right to make use of an item of property, the provision of a service, transport, insurance, banking operations, etc. - which usually constitutes the centre of gravity and the socio-economic function of the contractual transaction.

Aiming to simplify the determination of the governing law, Articles 4(2) of the Convention and the Regulation locate the characteristic performance in order to establish the relevant connecting factor at the habitual residence of the party liable for its performance at the time of the conclusion of the contract. ${ }^{26}$ Hence, the determination of the applicable law under paragraph 2 is not dependent upon the place of performance that may be more difficult to establish.

Intellectual or industrial property rights may be involved in agreements in different forms. They may be the main or sole object of a simple or mixed licence or transfer agreement, but they may also be part of a package deal of other contracts, such as an engineering contract or a joint-venture agreement. As regards the basic types of contracts relating to intellectual or industrial property rights, the prevailing view is that it is possible to determine the performance of one of the parties as characteristic. Simple transfer or assignment of rights and simple li-

\footnotetext{
${ }^{26}$ For the sake of legal certainty, Article 19 Rome I Regulation includes a definition of habitual residence, which in the case of companies and other bodies, shall be the place of central administration and which, in the case of a natural person acting in the course of his business activity, shall be his principal place of business. As an exception, according to Article 19(2), where the contract is concluded in the course of the operations of a branch, agency or any other establishment, or if, under the contract, performance is the responsibility of such a branch, agency or establishment, the place where the branch, agency or any other establishment is located shall be treated as the place of habitual residence.
} 
cences are considered to be the basic types of contracts in this area. Transfer equals assignment of ownership, and licence equals granting the right to use. By contrast to licence agreements, the transferee wishes to acquire the IP right and not only to participate in its use. Therefore, transfer of IP rights resembles sale contracts and licence is similar to the concept of lease. The basic idea of licensing agreements is that the owner of an exclusive IP right or know-how permits the licensee to enjoy it in return for payment. Hence, the licensor confers the right to use a species of technology, or the subject matter of another IP right, and the licensee seeks to participate in the legal or effective exclusivity of the licensor. As industrial and intellectual property rights consist of a bundle of rights, the bundle may be split into its component parts for the purpose of licensing. Contrary to simple transfer or simple licence, mixed agreements combine in their object more than one type of subject matter, such as patent, design, trademarks or copyright. Mixed licences whose subject matter includes patents and unpatented secret technology (know-how) are also very common.

The prevailing opinion is that the party who is to effect the characteristic performance in typical assignment or transfer of rights contracts is the assignor or transferor. ${ }^{27}$ Characteristic is the performance of ceding the exclusive right to which the legal protection is bound. Also, it is widely accepted that the characteristic performance in basic licence contracts whose content consists of the permission granted by the owner of the IP right (or know-how) to enjoy it in return for payment is that of the licensor. ${ }^{28}$ With regards to authors' rights this criterion has the advantage of referring to the law of the country in which the author has his residence and hence leads typically to the application of the law of the country of residence of the party who is considered the weaker party. Furthermore, it is noteworthy that the Report on the 1980 Rome Convention mentions as an example that in bilateral contracts in which the counter-performance by one of the parties takes the form of money, it is clear that 'the granting of the right to make use of an item of property' by the other party is the characteristic performance. This criterion decisively influenced Article 4(1)(f) of the 2005 Rome I Proposal, and its

\footnotetext{
${ }^{27}$ KREUZER K., 'Know-how-Verträge im deutschen Internationalen Privatrecht', in: Festschrift für E. von Caemmerer, Tübingen 1978, at 705 and 723; VIVANT M., 'Régime international', in: J.-Cl. dr. comm., 'Brevets', Fascicule 560, Paris 1992, p. 1 et seq., at 15; and ZENHÄUSERN U., Der internationale Lizenzvertrag (note 4), at 113.

${ }^{28}$ VIDA A., 'Les contrats de licence en droit international privé', in: Rev. crit. dr. int. pr. 1964, at 209 and 222-223; UlMER E., Intellectual Property Rights and the Conflict of Laws, Luxembourg 1978, at 93-95 and 102; LANDO O., 'Contracts', in: Int.Enc.Comp.L., vol. III chapter 24, 1976, at 142; VIVANT M. (note 27), at 15; DESSEMONTET F., 'Les contrats de licence en droit international privé', in Mélanges G. Flattet, Lausanne 1985, at 435 and 450-452; CABANELLAS G., 'Applicable Law under International Transfer of Technology Regulations', in: IIC 1984, at 39 and 54-57; SCHWANDER I., 'Die Behandlung der Innominatverträge im internationalen Privatrecht', in: Innominatverträge, Festgabe W.R. Schluep, Zurich 1988, at 501 and 509; LAGARDE P., 'Le nouveau droit international privé des contrats après l'entrée en vigueur de la Convention de Rome du 19 juin 1980', in: Rev. crit. dr. int. pr. 1991, at 287 and 307; ZENHAÜSERN U. (note 4), at 110; HiESTAND M. (note 4), at 183-193; MARTINY D., 'Art. 28', in: MünchKommBGB, $4^{\text {th }}$ ed., München 2006, at 1854 and UBERTAZZI B., 'La ley aplicable a los contratos de transferencia de tecnología', in: ADI 2006-2007, at 447 and 461. See also paragraph 315 ALI Principles Governing Jurisdiction, Choice of Law, and Judgments in Transnational IP Disputes.
} 
Explanatory Memorandum insisted on the idea that the determination of the characteristic performance was controversial for distribution and franchise contracts but not in the case of contracts relating to IP rights. ${ }^{29}$

Such a view has been countered by arguing that in most licence agreements the licensee's obligations go far beyond the payment of money, and hence, the licensee is the characteristic performer. ${ }^{30}$ Usually licensor and licensee enter into additional obligations including but not limited to issues such as registration of the license, technical assistance, warranties and guarantees, obligation to use, infringement reports and actions, quality control, changes and improvements, sublicenses, supply of goods, marking, marketing, confidentiality. In this connection, the following view has gained acceptance: to the extent that the license is exclusive or the licensee assumes the obligation to exploit the subject matter of the contract (patent, trademark, know-how, copyright, etc.), the licensee is the party who effects the characteristic performance. ${ }^{31}$ Due to the complex nature of licence agreements it has also been advocated that determining the characteristic performance requires a case by case analysis. ${ }^{32}$

In the framework of Article 4 Rome I Regulation, it is particularly noteworthy that the view that the transferor or licensor is the party who assumes the characteristic performance seems in line with the main features of the characteristic performance doctrine as stated by its creators. ${ }^{33}$ In fact, those who favour the application of the law of the licensee or the place of exploitation have traditionally criticized the characteristic performance doctrine as leading to unfair results that strengthen the dominant position of the providers of technology in the context of contracts relating to industrial property rights. ${ }^{34}$ Nonetheless, recourse to the characteristic performance has been the choice made by the EU legislator in Article 4(2) Rome I Regulation. Additionally, reference to the characteristic performance in Article 4 has to be interpreted in such a way as to ensure the basic aim of the Regulation that the conflict-of-law rules are highly predictable. In this regard, a systematic interpretation of that provision in accordance with the doctrine of the characteristic performance favours the view that the law of the habitual residence of the transferor or licensor shall normally be the decisive factor under Article 4(2).

The idea that if the licence is exclusive or the licensee is obliged to exploit the licensed rights, he should always be considered under Article 4(2) the party who effects the characteristic performance seems to raise significant difficulties. The criterion based on the exclusive character of the licence does not seem reliable and in certain cases it is not possible to decide that issue without consulting the

\footnotetext{
${ }^{29}$ COM (2005) 650 final, at 6.

30 Modiano G., Le contrat de licence de brevet, Geneva 1979, at 138-141: and SAJKO K., 'International-privatrechtliche Fragen internationaler Lizenzverträgen (Betrachtungen aus jugoslawischer Sicht)', in: GRUR Int 1986, at 239 and 241-242.

${ }^{31}$ ULMER E. (note 28), at 94.

${ }^{32}$ RoY A., Lizenzverträge im Verkehr zwischen der Bundesrepublik Deutschland und der Republik Polen, Frankfurt 1991, at 218.

${ }^{33}$ SCHNITZER A.F., Handbuch des internationalen Privatrechts, vol. II, $4^{\text {th }}$ ed., Basel 1988, at 597.

${ }^{34}$ SOLTYSIŃSKI S., 'Choice of Law and Choice of Forum in Transnational Transfer of Technology Transactions', in: Recueil des Cours 1986, t. 196, at 239 and 315.
} 
law of the contract. Concerning the obligation to exploit, it is noteworthy that the existence of such an obligation is basically linked to the way in which the price is determined. Such an obligation may or may not be included in the contract simply depending on the drafting of other clauses that may ensure the licensor a minimum payment regardless of the effective exploitation by the licensee. A significant disadvantage of making the law of the contract dependent on the obligation to exploit is that the governing law - the lex contractus but also in some situations the lex loci protectionis applicable to determine the transferability of the IP rights and the conditions under which a licence can be granted - may be decisive determining if such an obligation exists. Hence, that criterion may prove a source of uncertainty inasmuch as the law applicable to the contract depends on an issue that is to be decided under that law. To determine the law of the contract, it is necessary to establish if the contract includes an obligation to exploit; however, that is an issue to be determined under the law applicable to the contract. Thus, this criterion may lead to a vicious circle. ${ }^{35}$ Indeed, the determination and extent of such obligation varies between legal systems and in most legal systems is a controversial issue not always easy to ascertain. ${ }^{36}$ Additionally, such a view seems to contradict the basic idea - stated, for instance, in the report to the 1980 Rome Convention - that under the characteristic performance doctrine in a bilateral contract in which the main obligation of one party is to grant the right to make use of an item of property it is the grantor who effects the characteristic performance. It is clear that those contracts are typically concluded because the other party intends to use the item and that is also common in transfer and licences of IP rights. Furthermore, although the traditional patent licensing contract refers to the permission by the licensor to use or exploit the rights and the obligation not to assert infringement claims based on those rights against the licensee, the licensor usually has to afford the licensee every assistance in the exercise of the right to use he has provided. The licensor additionally usually has to provide guarantees as to the IP rights. That result also seems particularly clear in the case of agreements aimed at providing technical assistance to the licensee because they typically include obligations such as training of technicians and production counselling. Further, in regards to know-how licence agreements, the view of a mere waiver by the licensor of (unfair competition) claims is never appropriate due to the secret nature of the knowledge. Even if understood broadly as covering non-secret technology, these contracts focus on the transfer of technical knowledge and skills because the licensee is not able to use the technology without assistance. ${ }^{37}$

Notwithstanding the idea that the assignor or the licensor is in principle the party that effects the characteristic performance in a contract having as its main subject

\footnotetext{
${ }^{35}$ De Miguel Asensio P.A. (note 5), at 291-292; AzZi T. (note 20), at 33.

${ }^{36}$ For the complex interpretation of that point under German substantive law, see PAHLOw L., Lizenz und Lizenzvertrag im Recht des Geistigen Eigentums, Tübingen 2006, at 330-334 and 419423.

${ }^{37}$ PfAFF D., 'International Licensing Contracts, Transfer of Technology and Transnational Law', in: The Transnational Law of International Commercial Transactions, Deventer 1982, at 199 and 203.
} 
matter the assignment or license of an intellectual or industrial property right, it is important to note that the typology of contracts relating to intellectual or industrial property rights is very diverse. In practice, these contracts include categories of agreements in which the characteristic performance corresponds to the other party, contracts in which no characteristic performance can be determined, and contracts that are manifestly more closely connected with a country rather than that of the habitual residence of the transferor or licensor.

When making the determination of the characteristic performance, it may happen that the licensing or even the transfer of rights is functionally subordinate to activities or obligations that the other party has to effect under the terms of the contract. Under those circumstances, typically it will be possible to establish that the other party is the characteristic performer. That may be the case with development contracts ${ }^{38}$ or production and supply contracts. As noted earlier in the framework of Article 4 those contracts may qualify as contracts for the provision of services or supply of goods and be covered by paragraph 1 . For instance, that may also be the case with certain adaptation or translation agreements in which the author is the party who authorises the adaptation but the other party is who effects the characteristic performance. Additionally, in the case of publishing agreements under the relevant national provisions, they constitute a type of contract different from licensing contracts and have their own essential characteristic. The publishing house organizes the reproduction and distribution of the work. It is the publisher who usually is the only party acting in the course of his trade or profession and his performances are the most relevant when considering the function which the legal relationship involved fulfils in the economic and social life of any country. In typical situations, the performance of the publisher is the economic purpose of the contract. Therefore, it seems reasonable to conclude that under those circumstances the publisher is the party that effects the characteristic performance. $^{39}$

Furthermore, given the complex nature of certain agreements the best way to avoid arbitrary or forced solutions is to accept the limitations of the characteristic performance doctrine. ${ }^{40}$ Indeed, in very complex contracts whose structure and content has little in common with typical transfer or licence agreements, it seems appropriate to conclude that it is not possible to determine the party who is to effect the characteristic performance. That may be the case, for instance, in certain agreements which are common in the software industry, such as joint development agreements or developer-publisher licence agreements involving close cooperation between the developer and the publisher even before the development begins.

\footnotetext{
${ }^{38}$ KREUZER K. (note 27), at 727.

${ }^{39}$ Hiestand M. (note 4), at 189-190; Josselin-Gall M., Les contrats d'exploitation du droit de propriété littéraire et artistique, Paris 1995, nums. 310 et seq; OBERGFELl E.I., in: REITHMANN C. / MARTINY D. (note 10), at 1267 and 1294-1297.

${ }^{40}$ Stressing such limitations, see FAWCETT J. / TORREMANS P., Intellectual Property and Private International Law, Oxford 1998, at 551 et seq.
} 


\section{Recourse to the Escape Clause}

Even if a contract falls within one of the categories listed in paragraph 1 or if it is possible to determine its characteristic performance, the law indicated in Article 4 paragraphs 1 and 2 shall not apply if the contract is manifestly more closely connected with another country. Although the functioning of the escape clause requires restraint to ensure reasonable certainty, such clause may be relevant in an important number of situations concerning contracts relating to intellectual or industrial property rights. In the context of Article 4 Rome I Regulation, the key issue to be addressed is if, in situations that fall within paragraph 1 or the characteristic performance can be determined, it is possible to establish that certain contracts relating to intellectual or industrial property rights are manifestly more closely connected with another country pursuant to the terms of paragraph 3 .

In order to determine if such a manifestly closer connection exists, a relevant factor is the existence of a very close relationship of the contract in question with another contract or contracts, as stated in the Preamble to the Rome I Regulation (paragraph 20). This element may be relevant in situations where international transfer or licence of IP rights are a part of a broader and more complex project arranged through a number of contracts. Under those circumstances, it is possible that there are good practical reasons for deciding that the various contracts arising out of the project were governed by the law of the same country. ${ }^{41}$ For instance, it may happen that a licence agreement appears as functionally subordinate or accessory to the main agreement that covers the central aspects of the cooperation project. Where a choice of law has not been made by the parties in the licence agreement, its relationship with the other contracts arising out of the project may be relevant in the context of Article 4(3). Such relationship may be the basis to disregard the law applicable to the licence contract resulting from Article 4(2) and to appreciate that a manifestly closer connection exists with the law applicable to the other contract(s) concerning the project, so that inasmuch as possible the same law applies to the whole deal.

When analyzing agreements whose main object is the transfer or licence of an intellectual or industrial property right, it is important to note that the specific nature of intellectual and industrial property rights may decisively affect the existence of special links between the contract and one country. The view that contracts whose object is industrial or intellectual property rights of one country are clearly most closely connected with that country (country of protection) has found

\footnotetext{
${ }^{41}$ KreUZER K. (note 27), at 719; VON DER SEIPEN C., Akzessorische Anknüpfung und engste Verbindung im Kollisionsrecht der komplexen Vertragsverhältnisse, Heidelberg 1987, at 272-273; JAYME E., 'Kollisionsrechtliche Techniken für Langzeitverträge mit Auslandsberührung', in: NiCKLISCH F. (Hsgb.), Der komplexe Langzeitvertrag (Strukturen und Internationale Schiedsgerichtsbarkeit), Heidelberg 1987, at 311 and 313; VISCHER F., 'Das Internationale Vertragsrecht nach dem neuen schweizerisches IPR-Gesetz', in: Das neue Bundesgesetz über das Internationale Privatrecht in der praktischen Anwendung, Zurich 1990, at 9 and 29; MARTINY D., in: REITHMANN C. / MARTINY D. (note 10), at 163-167.
} 
significant acceptance. ${ }^{42}$ These exclusive rights are limited to specific territories and to the extent that a contract only refers to rights of a single country, it is certain that most facts and activities relevant to the performance of the contract shall always take place in the country of protection. The scope and effects of those rights are limited to the territory of the state that grants them, and hence, they can only be exploited within the country of protection. In the case of rights subject to registration, as is common in the field of industrial property rights, the integration of the subject matter in the social and economic sphere of the country of registration is especially clear. Nonetheless, such integration and special relationship with the country of protection is also present in the case of intellectual or industrial property rights not subject to registration due to them also being territorial.

The implementation of the contract requires that both parties perform continuous obligations in that territory. Additionally, the law of protection, as a consequence of the mandatory conflict-of-law rules on intellectual or industrial property rights, shall govern certain issues relevant to the contract regardless of the law of the contract. Those issues usually cover, ${ }^{43}$ in particular: the existence, validity, duration, scope and contents of the exclusive rights; whether and under what conditions a right may be transferred; the conditions under which licences can be granted, and; whether and under what conditions a transfer or licence is effective against third parties. ${ }^{44}$ Given that a breach of contract may take the licensee's activity into the area of infringement, there is significant interplay between the law of the contract and the law applicable to non-contractual obligations. Furthermore, because the main obligations arising out of the contract have to be performed in the country of protection, overriding mandatory provisions of that country such as antitrust laws are normally applicable to the contract due to its close connection with that country. In the case of agreements on copyright, specific rules establishing limits on transferability and the extent and conditions of transfers and licences are an important part of national copyright legislation aimed at protecting the author as the weaker party in typical contractual situations. Such provisions usually fall under the scope of application of the lex loci protectionis as a result of the conflict-of-law rules on intellectual property rights and therefore apply regardless of the law applicable to the contract. ${ }^{45}$ That approach ensures the protection of authors in international contracts. Given this situation, it can be

42 Troller A., Immaterialgüterrecht, Vol. II, $3^{\text {rd }}$ ed, Basel 1985, at 863-864; BLAISE J.B. / STENGER J.P., 'Propriété industrielle', in: J.-Cl. dr. int., Fascicule 563-A, Paris 1981, at 28; DE Miguel Asensio P.A. (note 5), at 267-276; MARTiny D., 'Art. 28', in: MünchKommBGB, $4^{\text {th }}$ ed, 2006, at 1855; UBERTAZZI B. (note 28), at 462.

${ }^{43}$ SOLTYSIŃSKI S. (note 34), at 294-307; ZENHÄUSERN U. (note 4), at 88-89; HIESTAND M. (note 4), at 98-122; De Miguel Asensio P.A. (note 5), at 168-185; and LóPEZ-TARRUELla MARTínEZ A., Contratos internacionales de software, Valencia 2006, at 269-297; AZZI T. (note 20), at 45-47.

${ }^{44}$ FAWCETT J. / TORREMANS P. (note 40), at 546.

${ }^{45}$ MetzGer A., 'Transfer of Rights, License Agreements, and Conflict of Laws: Remarks on the Rome Convention of 1980 and the Current ALI Draft', in: BASEDOW J. / DreXL J. / KUR A. / METzGer A. (note 6), at 61-77 and 66-73; SCHACK H., 'Internationally Mandatory Rules in Copyright Licensing Agreements', ibid, at 107-117 and 116; AZZI T. (note 20), at 45. 
concluded that the contract is to a great extent manifestly integrated in the sphere of the country of protection.

The idea that transfer and licence contracts whose subject matter is industrial or intellectual property rights of only one country are manifestly more closely connected with the country of protection may to a certain extent be founded on the same rationale as the special rule on contracts to a right in rem in immovable property or to a tenancy of immovable property. ${ }^{46}$ Under Article 4(1)(c) Rome I Regulation, those contracts shall be governed by the law of the country where the property is situated. The rule is based on the idea that, given its subject matter, the centre of gravity of those contracts is located in that country. A clearly closest connection with the sole country of protection cannot be established under Article 4(3) in situations where the contract has special links with another country. For instance, this may be the case when licensor and licensee have their common habitual residence in a country other than the country of protection of the licensed rights.

The idea that under Article 4(3) the law applicable to contracts relating to intellectual or industrial property rights of only one country shall be the law of protection may raise certain problems. It has been stressed that such an approach leads to different solutions for one-country and multi-country licence agreements. ${ }^{47}$ Nonetheless, such diverse treatment seems reasonable to the extent that only in the case of one-country IP contracts a manifest more closely connection with the sole country of protection can typically be established. Also, the special rule of Article 4(1)(c) applies to the extent that a contract relates to immovable property located only in one country, although multi-country agreements on immovable property are less frequent. It also results in a criterion that, in typical situations, is easy to determine and apply. In principle, the close connection with the country of protection is not functional with respect to contracts relating to supranational IP rights such as Community trademarks, although its rationale may be influential as regards the application of Article 4(3) and 4(4) to those contracts.

With a view to extend a similar approach to multi-state licence agreements, it has been argued that sometimes it is possible to identify one of the protecting countries as the primary country of protection and exploitation. If the essential acts of production, exploitation and marketing take place in one of the protecting countries, that almost always is also the place of the seat of the licensee. ${ }^{48}$ However, in cases where a characteristic performance can be determined, recourse to the escape clause is to be limited to exceptional circumstances and hence should apply only to the extent that it is undisputed that the so-called primary country of protection is clearly most closely connected with the contract than is the country of the habitual residence of the characteristic performer.

It has also been noted that application of the law of protection to one-country intellectual or industrial property contracts under Article 4(3) leads to the application of different connecting factors to one-country patent contracts and to know-

\footnotetext{
${ }^{46}$ HiESTAND M. (note 4), at 281-289.

${ }^{47}$ ULMER E. (note 28), at 92-93.

${ }^{48}$ BEIER F.K., 'Conflict of Law Problems of Trademark License Agreements', in: IIC 1982, at 162 and 175-177; and TORREMANS P. (note 4), at 404-409.
} 
how agreements. That may pose difficulties given that in practice mixed licences whose subject matter includes know-how and patents or other IP rights are very common. ${ }^{49}$ However, differences as to their subject matter between patent agreements and know-how agreements may justify the diverse results in the application of Article 4 Rome I Regulation due to the fact that only one-country patent agreements can present the connection with the country of protection required under Article 4(3). Thus, mixed patent and know-how licences may combine obligations falling within categories of contracts (one-country patent licences and know-how licences) to which different connecting factors may apply under Article 4. Given the function of Article 4(3), only to the extent that exclusive industrial or intellectual property rights (and not know-how) are clearly the main object of the contract, a manifestly more closely connection with the law of the protecting country can be established in the case of mixed contracts that include know-how and industrial or intellectual property rights of a single country. Otherwise, the law of the habitual residence of the party who is to effect the characteristic performance should apply.

\section{Determination of the Country with the Closest Connection to the Contract}

Article 4(4) Rome I Regulation establishes a flexible default rule based on the location of the centre of gravity or the most significant relationship of the contract in line with Article 4(5) Rome Convention. That provision provides the formula to determine the law of the contract in the absence of choice, where the applicable law cannot be determined under Article 4(1) of the Regulation, since the contract cannot be categorised as one of the specified types nor under paragraph 2 because it is not possible to determine the country of habitual residence of the party required to effect the characteristic performance. In these situations the governing law shall be the law of the country with which the contract is most closely connected.

Such situations may be frequent in the field of contracts relating to industrial or intellectual property rights to the extent that in some of these contracts the characteristic performance may be impossible to determine. That is the case of socalled reciprocal agreements or licence exchange contracts. These agreements are usually concluded between parties who mutually waive their industrial property rights because they cannot perform their activities without infringing on each other's rights. Therefore, the two parties grant each other a licence; usually, these licences concern similar IP rights. It is thus impossible to single out the main performance of one of the parties as characteristic. Additionally, transfer and licences of industrial or intellectual property rights take place many times as part of the subject matter of a complex agreement that combines in a single contract a bundle

\footnotetext{
${ }^{49}$ Ulmer E. (note 28), at 92-93; VON HofFMANN B., 'Verträge über gewerbliche Schutzrechte im internationalen Privatrecht', in: RabelsZ 1976, at 208 and 214; and HIESTAND M. (note 4), at 304311.
} 
of rights and obligations typical of different categories of contracts. For instance, this may be the case in certain cooperation contracts. As noted earlier, in complex contracts whose structure and content has little in common with typical transfer or licence agreements, it is usually not possible to determine the party who is to effect the characteristic performance.

The Rome I Regulation does not provide in principle any criteria to determine the country with which the contract is most closely connected under paragraph 4 . Its Preamble also stresses in this connection the idea that account should be taken, inter alia, of whether the contract in question has a very close relationship with another contract or contracts. In general terms, not only a single circumstance is decisive and a wide range of factors must be taken into consideration. With a view to determining certain factors that must be taken into account and weighing them, it is important to consider that the ideas on which the rules established in Article 4 paragraphs 1 and 2 are based should play a significant role because they are considered as the most relevant elements indicating the centre of gravity of the international contracts in the contracts they cover. ${ }^{50}$

Therefore, the most significant factors include the place of residence or business of the parties and their nationality, which may be decisive if both are residents of the same country or are of the same nationality. It may also be very important to consider the subject-matter of the contract and the place of performance if the contract is more integrated in the social and economic sphere of one country. These factors may be decisive if the contract only covers industrial or intellectual property rights of one country or if it possible to determine a so-called primary country of protection. Other relevant factors to be considered include the structure and content of the contract, the place where the negotiations have been held, and the place of contracting.

${ }^{50}$ De Miguel Asensio P.A. (note 5), at 264-267; and MARTiny D. (note 10), at 149-159. 